\title{
PEMBAGIAN HARTA BERSAMA MENURUT HUKUM ISLAM
}

\author{
Hani Sholibab"
}

\begin{abstract}
The rule on dividing joint property and wealth between a busband and a wife is based on the customary law (urf) which divides balf of those wealth for each. This rule is also determined in UUNo $1 / 1974$ (Code of Mariage). Actually, 'urf is only a kind of consideration in defining the law and that should not be opposed to any rules.
\end{abstract}

Kata Kunci: harta bersama, tirkeab, dan bukum Islam.

\section{A. Pendahuluan}

Undang-Undang Nomor 1 Tahun 1974 tentang Perkawinan mengatur harta kekayaan dalam perkawinan pada Bab VII dalam item Harta Benda dalam Perkawinan. Pada pasal 35 ayat (1) dinyatakan bahwa harta benda yang diperoleh selama perkawinan menjadi harta bersama. Selanjutnya pasal 35 ayat (2) menjelaskan bahwa harta bawaan dari masing-masing suami dan isteri dan harta benda yang diperoleh masing-masing sebagai hadiah atau warisan adalah di bawah penguasaan masing-masing sepanjang para pihak tidak menentukan lain. ${ }^{1}$

'Penulis adalah Dosen pada Institut Agama Islam Cipasung Tasikmalaya dan mahasiswa Program Doktor pada Universitas Islam Negeri Sunan Gunung Djati Bandung.

'Lihat Undang-Undang Nomor 1 Tahun 1974 tentang Perkawinan. 
Dari kedua pasal tersebut dapat disimpulkan bahwa harta bersama adalah harta kekayaan yang diperoleh selama perkawinan di luar hadiah atau warisan. Jadi dengan kata lain, harta bersama adalah harta yang didapat atas usaha mereka atau sendiri-sendiri selama masa ikatan perkawinan.

Ketentuan harta bersama dalam Undang-Undang Perkawinan ini diperkuat dengan Kompilasi Hukum Islam (KHI) pada Buku I tentang Hukum Perkawinan Bab XIII tentang Harta Kekayaan dalam Perkawinan. Pasal 85 menyatakan bahwa harta bersama dalam perkawinan tidak menutup kemungkinan adanya harta milik masingmasing suami atau istri.

Sampai di sini tidak timbul permasalahan. Persoalan akan muncul apabila kedua suami-isteri itu berpisah (baik karena perceraian-cerai hidup- atau karena salah satu dari suami atau isteri meninggal duniacerai mati). Khusus perceraian karena mati, persoalan menjadi lebih kompleks karena berkaitan dengan penentuan warisan yang menjadi hak ahli waris.

Kompilasi Hukum Islam (KHI) pasal 96 ayat (1) menetapkan bahwa apabila terjadi cerai mati, maka separuh harta bersama menjadi hak pasangan yang hidup lebih lama. ${ }^{2}$ Artinya sebelum harta peninggalan dibagikan, terlebih dahulu harus diberikan separuhnya kepada pasangan (suami atau isteri) yang masih hidup sebagai bagian atas hak harta bersama dan bukan sebagai bagian dari hak warisan.

Persoalannya kemudian adalah apakah dalam Islam dikenal istilah harta bersama? Bagaimana penentuan bagian masing-masing suami atau isteri dari harta bersama? Apakah ketentuan seperti itu tidak bertentangan dengan sistem kewarisan Islam?

${ }^{2}$ Kompilasi Hukum Islam pada dasarnya merupakan bahan pertimbangan dalam penetapan hukum di Pengadilan Agama sebagaimana tertuang dalam Intruksi Presiden Nomor 1 Tahun 1991. 


\section{B. Harta Bersama dalam Islam}

Fatchur Rahman menyatakan bahwa sebelum harta peninggalan dibagikan kepada ahli waris, hukum Adat meneliti lebih dahulu macam dan asal harta peninggalan itu, apakah merupakan harta masing-masing pihak yang terpisah satu sama lain atau merupakan harta campur-kaya dari suami-isteri. ${ }^{3}$ Kelihatannya Fatchur Rahman mengakomodir hukum Adat ke dalam hukum kewarisan Islam.

Harta kekayaan yang diperoleh dari warisan di beberapa daerah mempunyai nama yang berbeda. Misalnya di Jawa disebut gono atau gavan, di Sumatera disebut pusaka, dan di Sulawesi disebut sisila. Pada umumnya, harta kekayaan ini menjadi milik masing-masing suami atau isteri. Apabila suami atau isteri meninggal dunia, harta tersebut diwarisi oleh anak-anaknya. Jika tidak meninggalkan anak, harta itu kembali kepada keluarga yang meninggal (suami atau isteri) dan tidak dapat beralih kepada ahli waris yang lain.

Sedangkan harta kekayaan yang diperoleh secara hibah atau hasil usaha sendiri dapat diwarisi oleh anak dan isteri atau suami yang masih hidup dengan perbedaan penerimaan antara satu daerah dengan daerah lainnya. Sebagian daerah menetapkan bagian isteri yang ditinggalkan $1 / 8$ dan sebagian daerah lain justru tidak memberikan hanya hak mendapatkan nafkah sampai meninggal dunia. ${ }^{4}$

Adapun harta bersama adalah harta kekayaan yang diperoleh suami dan isteri selama dalam perkawinan, dimana keduanya bekerja untuk kepentingan hidup berumah tangga. Menurut Fatchur Rahman, ${ }^{5}$ pengertian "bekerja" hendaknya diartikan secara luas sehingga seorang isteri yang pekerjaannya tidak secara nyata menghasilkan kekayaan (materi) seperti memelihara dan mendidik anak-anaknya dianggap bekerja. Dan harta yang diperoleh secara kongkrit oleh suami menjadi milik bersama. Harta bersama ini disebut gono-gini (Jawa), guna-kaya

${ }^{3}$ Fatchur Rahman, Ilmu Waris, (Bandung: PT. al-Ma'arif, 1987), hal. 40-41.

${ }^{4}$ Ibid.

5Ibid. 
atau campur kaya (Jawa Barat), harta suarang (Sumatera Barat), dan bareuta seubareukat (Aceh).

Pada prinsipnya baik suami maupun isteri dapat melakukan transaksi terhadap harta milik bersama. Namun Soerojo Wignjodipoero menyatakan bahwa dalam transaksi sebaiknya dilakukan bersama. Tetapi suami dapat melakukannya sendiri jika persetujuan isteri dianggap sudah ada. ${ }^{6}$

Jika terjadi perceraian, harta milik bersama ini dibagi antara kedua belah pihak (suami dan isteri). Masing-masing pada umumnya menerima separuh. Meskipun ada beberapa daerah yang mempunyai kebiasaan membagi seperti sagendong sapikul (Jawa) dan sasubun sarembat (Bali). Sementara jika salah seorang (suami atau isteri) meninggal dunia, maka harta bersama itu dikuasakan kepada yang masih hidup dengan ketentuan bahwa kelebihan pembagian dijadikan harta waris bagi ahli warisnya.?

Sementara itu pasal 96 ayat (1) Kompilasi Hukum Islam (KHI) menetapkan bahwa apabila terjadi cerai mati, maka separuh harta bersama menjadi hak pasangan yang hidup lebih lama. ${ }^{8}$ Penentuan pembagian harta bersama (sebelum dibagi waris) separuh bagian dalam pasal 26 Kompilasi Hukum Islam (KHI) merupakan langkah berani yang dasar metodologisnya adalah kebiasaan masyarakat ('urf) yang secara materiil disebut dengan harta gono-gini.?

Selanjutnya Ahmad Rofiq menjelaskan bahwa istilah harta bersama secara múamalat dikategorikan sebagai syirkab dengan konteks kebutuhan ekonomi keluarga dibebankan kepada suami, sedang isteri bertindak sebagai pengatur ekonomi keluarga (syirkab 'abdan) yang juga

${ }^{6}$ Soerojo Wignjodipoero, Pengantar dan Asas-asas Huksm Adat, (Jakarta: Gunung Agung, 1995), hal. 157.

'Tbid., hal. 159.

${ }^{8}$ Demikian juga halnya jika terjadi cerai hidup, pasal 97 Kompilasi Hukum Islam (KHI) menyatakan bahwa janda atau duda cerai hidup masing-masing berhak seperdua dari harta bersama sepanjang tidak ditentukan lain dalam perjanjian perkawinan.

'Ahmad Rofiq, Hukum Islam di Indonesia, cet. 6 Jakarta: PT. RajaGrafindo Persada, 2003), hal. 209. 
dapat melakukan pekerjaan yang dapat mendatangkan kekayaan yang dikelola bersama (syirkah 'iñan). ${ }^{10}$ Setidaknya pemahaman seperti dilandasai oleh kenyataan bahwa secara umum suami-isteri sama-sama bekerja untuk mendapatkan nafkah hidup keluarga. ${ }^{11}$

Senada dengan di atas, Satria Effendi, ${ }^{12}$ menyatakan bahwa apa yang disebut harta bersama pada mulanya didasarkan atas 'urf yang tidak memisahkan antara hak milik suami dan isteri. Artinya akad nikah mengandung pengertian persetujuan dalam membina kehidupan rumah tangga termasuk harta yang diperoleh setelah akad nikah dianggap harta bersama tanpa mempersoalkan siapa yang lebih banyak dalam usaha memperoleh harta tersebut. ${ }^{13}$

\section{Pembagian Harta Bersama}

Dalam al-Qur'an tidak dibicarakan tentang harta bersama dalam kaitannya sebagai tirkab (harta warisan) atau sebagai harta yang harus dibagi dua sebelum ditentukan harta warisannya. Berbeda dengan wasiat dan hutang yang harus diselesaikan sebelum harta warisan dibagikan, seperti terlihat pada surah al-Nisâ' ayat 12 .

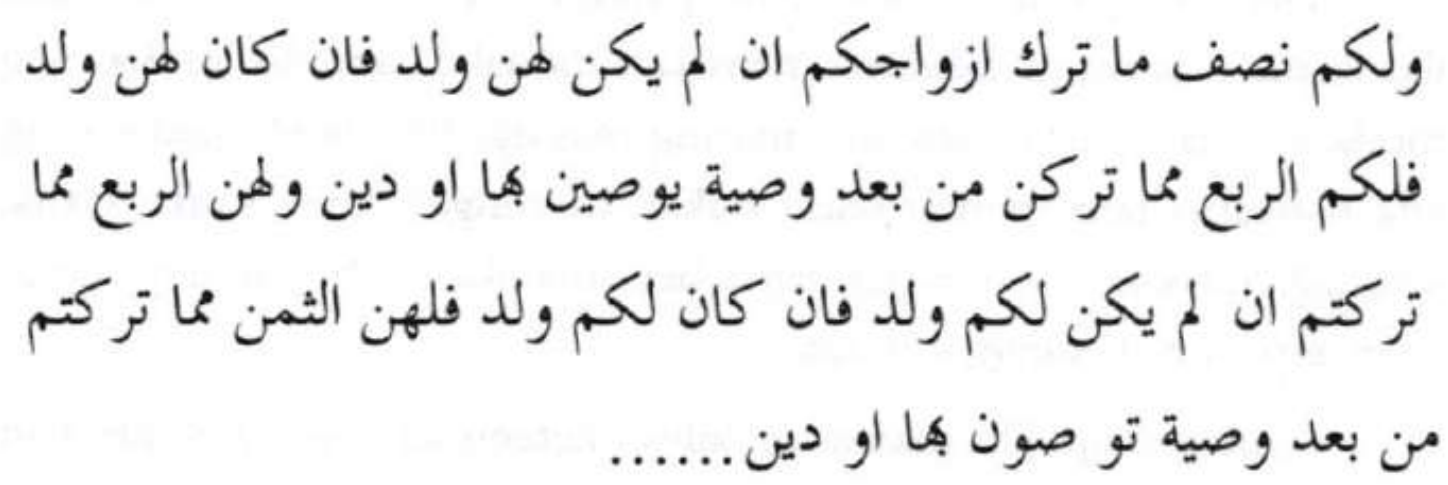

${ }^{10}$ Ibid., hal. 200.

"Yahya Harahap, Kedudukan, Kewenangan, dan Acara Peradilan Agama (Undang-Undang Nomor 7 Tahun 1989), cet. 2 (Jakarta: PT. Garuda Metropolitan Press, 1993), hal. 297.

${ }^{12}$ Satria Effendi, Problematika Hukum keluarga Islam Kontemporer: Analisis Yurisprudensi dengan Pendekatan Usbuliyab, (Jakarta: Kencana, 2004), hal. 59-61.

${ }^{13}$ Senada dengan pernyataan pasal 1 huruf $\mathrm{f}$ Kompilasi Hukum Islam (KHI) yang berbunyi: Harta kekayaan dalam perkawinan atau syirkah adalah harta yang diperoleh baik sendiri-sendiri atau bersama-sama suami-isteri selama dalam ikatan perkawinan berlangsung dan selanjutnya disebut harta bersama tanpa mempersoalkan terdaftar atas nama siapa-pun. 
Pada ayat di atas, dinyatakan secara tegas bahwa suami mendapatkan bagian seperdua dari harta yang ditinggalkan oleh istri, jika istri tidak mempunyai anak dan seperempat jika istri mempunyai anak setelah dilaksanakan wasiat atau dibayarkan hutangnya. Sebaliknya apabila suami meninggal, maka istri mendapatkan seperempat dari harta yang ditinggalkan suaminya apabila suami tidak mempunyai anak dan seperdelapan jika suami mempunyai anak setelah dilaksanakan wasiat dan atau dibayarkan hutangnya. Ini menunjukkan bahwa ketentuan harta bersama tidak dikenal dalam al-Qur'an.

Quraish Shihab ketika menguraikan ayat ini menyatakan:

"seperdua yang ditinggalkan isteri atau suami adalah harta yang mereka tinggalkan yang tadinya merupakan hak penuh mereka. Jika suami-istri menanam modal untuk satu usaha dan bekerja sama, maka apa yang ditinggalkan itu harus terlebih dahulu dipisahkan hak masing-masing (suami-isteri) sebelumnya. Setelah ditetapkan dan dipisahkan dari harta yang ditinggal, barulah harta yang menjadi hak penuh salah seorang yang meninggal dunia itu dibagi sesuai dengan ketentuan al-Qur'an". ${ }^{14}$

Dari pernyataan tersebut, tampaknya harta bersama baru ada, jika suami-istri secara bersama menanam modal dalam satu usaha yang modalnya dari harta (bawaan) masing-masing. Jika tidak, maka yang ada hanyalah perkawinan biasa bukan hubungan kerja sama usaha, sehingga tidak ada pembagian harta bersama jika salah satu dari suamiisteri tersebut meninggal dunia.

Akan tetapi jika dikatakan bahwa ketentuan tentang pembagian harta bersama didasarkan atas kemaslahatan, apakah itu tidak berarti memandang bahwa hukum waris yang ditetapkan syara' tidak cukup memberikan kemaslahatan ?

${ }^{14} \mathrm{M}$. Quraish Shihab, Tafsir al-Mishbab: Pesan, Kesan, dan Keserasian al-Qur'an, Jakarta: Lentera Hati, 2000) II: 349. 
Ketentuan waris yang telah ditetapkan oleh Allah sudah pasti sesuai dengan kemaslahatan. Demikian pula dengan ketentuan bagian suami dan istri. Jika suami (dari isteri yang meninggal dunia) mendapatkan bagian setengah dari harta bersama, kemudian mendapat bagian setengah lagi dari harta warisan istrinya (jika istri tidak mempunyai anak), maka suami mendapatkan bagian kurang lebih tiga perempat dari keseluruhan harta (yang dimiliki oleh suami istri tersebut selama perkawinan). Jika si istri mempunyai anak, maka setelah mendapat setengah bagian dari harta bersama, suami mendapat seperempat lagi bagian dari harta warisan. Akibatnya anak-anak si istri hanya akan mendapat sebagian kecil dari harta peninggalan ibunya.

Jika dikatakan bahwa bagian suami yang besar, maka itu wajar karena tanggung jawabnya untuk memberi nafkah keluarga dan membesarkan anak-anaknya. Dan bagian suami yang lebih besar dari isteri merupakan isyarat akan kewajiban tersebut. Karena apabila suami yang meninggal, istri mendapat seperempat dari harta peninggalan suami jika suami tidak mempunyai anak, dan hanya seperdelapan jika suami mempunyai anak. Artinya isteri mendapat bagian lebih kecil dari bagian suami, karena yang bertanggung jawab atas nafkah keluarga adalah suami. Oleh karena itu sangat tepat manakala al-Qur'an dalam surah al-Nisā' ayat 11 menyatakan:

“...(tentang) orang tuamu dan anak-anakmu, kamu tidak mengetahui siapa di antara mereka yang lebih dekat (banyak) manfaatnya bagimu. Ini adalah ketetapan dari Allah. Sesungguhnya Allah Maha Mengetahui lagi Maha Bijaksana".

Dalam mengkaji masalah ini, perlu kiranya memahami asas-asas kewarisan dalam Islam, antara lain:

1. Asas ijbäri (memaksa) dalam arti bahwa peralihan harta dari seorang yang meninggal dunia kepada ahli warisnya berlaku dengan sendirinya menurut ketetapan Allah tanpa dikaitkan kepada kehendak si pewaris atau ahli warisnya; 
2. Asas warathah (peralihan harta setelah kematian) yang berarti bahwa kewarisan itu hanya ada kalau ada yang meninggal dunia;

3. Asas thuluth al-mäl yang menyatakan bahwa wasiat tidak boleh melebihi sepertiga dari jumlah harta peninggalan;

4. Asas bilateral, dalam arti bahwa seseorang menerima hak atau bagian warisan dari kedua belah pihak, dari kerabat keturunan lakilaki dan dari kerabat perempuan;

5. Asas keadilan atau keseimbangan yang berarti bahwa senantiasa terdapat keseimbangan antara hak dan kewajiban, antara yang diperoleh seseorang dengan kewajiban yang harus ditunaikannya; dan

6. Asas individual yang mengandung arti bahwa harta warisan dibagikan kepada ahli waris untuk dimiliki secara personal. ${ }^{15}$

Dari keenam asas tersebut, asas ijbari dan keadilan atau keseimbangan yang mengandung arti bahwa peralihan harta dari seorang yang meninggal dunia kepada ahli warisnya berlaku dengan sendirinya menurut ketetapan Allah, tanpa digantungkan kepada kehendak si pewaris atau ahli warisnya. Unsur memaksa dalam hukum waris timbul karena kaum muslimin terikat untuk taat kepada hukum Allah sebagai konsekuensi dari pengakuannya kepada ke-Mahaesa-an Allah.

Adapun asas keadilan atau keseimbangan mengandung arti bahwa dalam kewarisan Islam, harta peninggalan yang diterima oleh ahli waris dari pewaris pada hakikatnya merupakan kelanjutan tanggung jawab pewaris terhadap keluarganya. Oleh karena itu bagian yang diterima oleh masing-masing ahli waris berimbang dengan perbedaan tanggung jawab masing-masing terhadap keluarganya. Seorang laki-laki menjadi penanggung-jawab kehidupan keluarga, yaitu mencukupi keperluan hidup anak dan isterinya (Q.S. al-Baqarah: 233) menurut kemampuannya (Q.S. at-Talāq: 7). Tanggung jawab itu merupakan kewajiban agama yang harus dilaksanakan, terlepas dari persoalan apakah isterinya

\footnotetext{
${ }^{15}$ Juhaya S. Praja, Filsafat Hukem Islam ,(Bandung: LPPM Unisba, 2004), hal. 107-
} 112. 
mampu atau tidak. Terhadap kerabat lain, tanggung jawab seorang lakilaki juga ada (QS. al-Baqarah: 177). Berbeda dengan laki-laki, tanggung jawab perempuan justru berhak menerima nafkah, maskan (tempat tinggal) dari suaminya. Dengan demikian sesungguhnya manfaat yang dirasakan oleh laki-laki dan perempuan dari harta peninggalan yang mereka peroleh adalah sama. ${ }^{16}$

Dengan asas keadilan dan keseimbangan tersebut jelas bahwa ketentuan kewarisan sudah mengandung nilai keadilan dan kemaslahatan. Demikian pula, jika dasar ketentuan harta bersama ini adalah 'urf rasanya kurang tepat, karena 'urf digunakan untuk membatasi atau menjelaskan sesuatu yang ditetapkan oleh syara'. ${ }^{17}$

Dengan Demikian, dapat dipahami bahwa 'urf tidak dipakai untuk menetapkan hukum,tetapi hanya untuk membatasi kemutlakan suatu hukum yang telah ditetapkan, seperti menetapkan batas minimal dan maksimal lamanya haid dan nifas, batasan balig, dan lain-lain dan tidak untuk melembagakan suatu hukum.

\section{Kesimpulan} berikut:

Dari pembahasan di atas, dapat diambil kesimpulan sebagai

1. Ketentuan tentang harta bersama dalam Undang-Undang Nomor 1 Tahun 1974 tentang Perkawinan dan Kompilasi Hukum Islam (KHI) tidak ditemukan ketentuan hukumnya dalam ketentuan

${ }^{16}$ Ibid., hal. 111.

${ }^{17}$ Sebagaimana perkataan al-Suyümi:

قال الفقهاء كلما ورد به الثر ع مطلقا ولا ضا بطاله فبه ولا في اللغة يرجع فيه الى العرف العناء

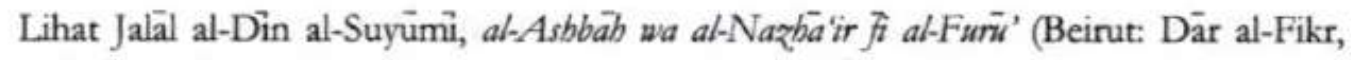
1990), hal. 69. Demikian juga al-Zarkashi, dengan perkataannya انها تحكم فيما لا ضبطا له شر عا

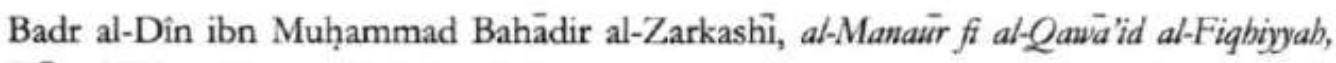
(Beirut: Där al-Fikr, t.t.), juz II, hal. 424. 
Islam;

2. Ketentuan pembagian harta bersama menggunakan 'urf hendaknya disesuaikan dengan kemaslahatan manusia sebagaimana diatur dalam ketentuan Islam;

3. Ketentuan harta bersama dapat diakui dalam pandangan hukum Islam selama pembagiannya tidak menyalahi ketentuan-ketentuan yang telah ditetapkan dalam hukum Islam.

\section{DAFTAR PUSTAKA}

Effendi, Satria. Problematika Hukum keluarga Islam Kontemporer: Analisis Yurisprudensi dengan Pendekatan Usbuliyah. Jakarta: Kencana, 2004.

Harahap, Yahya. Kedudukan, Kenvenangan, dan Acara Peradilan Agama (UndangUndang Nomor 7 Tabun 1989). Jakarta : PT. Garuda Metropolitan Press, 1993.

Praja, Juhaya S. Filsafat Hukum Islam. Bandung: LPPM Unisba, 2004.

Rofiq, Ahmad. Hukum Islam di Indonesia. Jakarta: PT. RajaGrafindo Persada, 2003.

Rahman, Fatchur. Ilmu Wuris. Bandung: PT. al-Ma’arif, 1987.

Shihab, M. Quraish. Tafsir al-Misbbab: Pesan, Kesan dan Keserasian al-Qur'an. Jakarta: Lentera Hati, 2000.

Al-Suyựị, Jalāl al-Din. Al-Asbbah wa al-Naz̧hā ir fỉ al-Furū'. Beirut: Dār al-Fikr, 1990.

Soerojo Wignjodipoero, Soerojo. Pengantar dan Asas-asas Hukum Adat. Jakarta: Gunung Agung, 1995.

Al-Zarkashi, Badr al-Din ibn Muhammad Bahādir. Al-Manthür fi al-Qawā'id alFiqbiyyah. Beirut: Dār al-Fikr, t.t.

Undang-Undang Nomor 1 Tahun 1974 tentang Perkawinan.

Intruksi Presiden Nomor 1 Tahun 1991 tentang Kompilasi Hukum Islam. 